DOI: $10.4274 /$ tpa.45.124

\title{
Ebeveyn besleme tarzı anketi geçerlik ve güvenirlik çalışması
}

\section{Reliability and validity study of parental feeding style questionnaire}

\author{
Mustafa Özçetin, Resul Yılmaz, Ünal Erkorkmaz*, Haluk Esmeray \\ Gaziosmanpaşa Üniversitesi Tıp Fakültesi, Çocuk Sağı̆ğı ve Hastalıkları Anabilim Dalı, Tokat, Türkiye \\ *Gaziosmanpaşa Üniversitesi Tıp Fakültesi, Biyoistatistik Anabilim Dalı, Tokat Türkiye
}

\section{Özet}

Amaç: Ebeveynlerin besleme alışkanlığını belirlemek için kullanılan, anne babanın cevapladığı, Parental Feeding Style Questionnaire (PFSQ) anketinin Türk çocuklarında geçerlik ve güvenirliğinin gösterilmesi amaçlanmıştır.

Gereç ve Yöntem: Bu kesitsel çalışmada çocuklarda yeme davranışı anketi Türkçe'ye uyarlandı. Anaokulu ve anasınıfı öğrencileri ile çocuk polikliniğine başvuran hastaların anne babalarına uygulandı. 650 anketin 468'i değerlendirmeye alındı. Faktör yapıları incelendi. Veriler istatistik paket programı ile değerlendirildi (PASW ver.18, ID:33478001 SPSS inc. Chicago, IL).

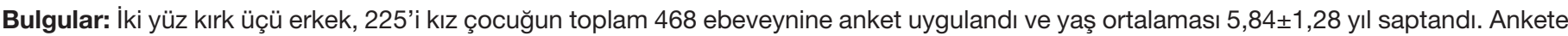
ait alt ölçeklerin Cronbach Alfa katsayıları ise 0,54 ile 0,83 arasında değişmiştir. Yapı geçerliği, iç tutarlığı ve alt grup ilişkileri açısından özgün anket ile çok yakın sonuçlar elde edilmiştir.

Çıkarımlar: Ebeveyn besleme tarzı ve çocukların kilosu arasındaki ilişkinin kanıtlarının, uzun süreli gözleme dayalı çalışmalar yoluyla ortaya koyulması gerekmektedir. Son yıllarda gözlemlenen șișmanlıktaki çarpıcı artıșlar ve özellikle çocukluk dönemindeki șișmanlık artıșı göz önüne alındığında, çocukluk döneminde şişmanlık gelişimi üzerine yapılacak araştırmalara yönelik yatırıma öncelik verilmesi gerekmektedir. (Türk Ped Arş 2010; 45: 124-31)

Anahtar sözcükler: Ebeveyn besleme tarzı, anket, geçerlik, güvenirlik

\section{Summary}

Aim: We aimed to confirm the validity and internal reliability of Parental Feeding Style Questionnaire (PFSQ) which was a parent-report measure and was designed to assess variations in parent's feeding styles.

Material and Method: For this cross sectional study, PFSQ was translated to Turkish and conducted among parents of both preschool students and patients who applied to the pediatric outpatient clinic. 468 of 650 responded questionnaires were examined for factor structure. The data were analyzed by PASW ver.18 and SPSS program.

Results: The questionnaire was conducted among parents of 243 boys and 225 girls, the mean age was $5.84 \pm 1.28$ Reliability coefficients (Cronbach Alphas) of subscales ranged from 0.54 to 0.83 Factor structure, internal reliability and subscale correlations were similar to original PFSQ.

Conclusions: Evidence for associations between parental feeding style and subsequent weight trajectory of children needs to be established through longitudinal follow-up studies.Given the dramatic increase in obesity that has been observed in recent years, and particularly the increase in childhood obesity, investment in research in the development of obesity in childhood should be given a high priority. (Turk Arch Ped 2010; 45: 124-31)

Key words: Parental feeding style, questionnaire, validity, reliability

\section{Giriş}

Çocukların sağlıklı büyümeleri ve gelişmelerinde beslenmenin önemi büyüktür. Beslenme tarzındaki bireysel farkllıklar hem zayıflık hem de fazla kilo ile ilişkilidir $(1,2)$. Çocuk, an- ne-babanın beslenme tarzı ve alışkanlıklarından etkilenir. Çocuklarda ilk öğrenme, yakın çevresindeki bireyleri taklit etme biçimindedir. Anne, baba ve kardeşler onlar için en iyi örnektir. Ailenin beslenme tarzının uzun süredir şişmanlığın nesiller arası aktarımasını desteklediği varsayılmaktadır.

Yazışma Adresi/Address for Correspondence: Dr. Mustafa Özçetin, Gaziosmanpaşa Üniversitesi Tıp Fakültesi, Çocuk Sağlığı ve Hastalıkları Anabilim Dalı, Tokat, Türkiye E-posta: mozcetin@gmail.com

Geliş Tarihi/Received: 09.11.2009 Kabul Tarihi/Accepted: 01.03.2010 
Klinik gözlemlere dayanan bu görüş yetişkin şişman hastaların düzensiz yeme alışkanlıklarının esas nedeni olarak anne ve babalarının beslenme tarzını sorumlu tutmaktadır $(3,4)$. Annelerin duygusal stresle baş etmek için yiyecek teklif etmeleri, bir ödül biçimi olarak yiyecek vermeleri, çocuğu istediğinden daha fazla beslenmesi için teşvik etmeleri ve bazı yiyeceklerin tüketilmesini kontrol etmeye çalışmaları şişmanlığın gelişmesine neden olabilecek önemli davranış biçimleridir $(5,6)$. Ebeveynlerin uyguladığı kontrolün koruyucu (örneğin, ebeveynler çocuğun kilosunu kontrol altında tutmak için bazı yiyeceklerin tüketilmesini kısıtlamaktadır) olduğu söylenebilir. Ancak ebeveynlerin uyguladığı kontrolün çocuğu kendi tüketimini düzenlemeyi öğrenmekten alıkoyacağına ilişkin bir görüş de bulunmaktadır. Gerçekten de ebeveynsel kontrol ile çocuğun ağırlığı arasında olumlu bir ilişkinin bulunması ebeveynlerin uyguladığı kontrolün çocuğun ağırlığını arttırdığı şeklinde yorumlanmıştır (7).

Yeni yapılan çalışmalarda psikolojik yaklaşımın yanı sıra şişmanlığın kalıtımsal olduğunun gösterilmesi ile biyolojik nedenler de araştııılmaya başlanmıştır. Şişman anne babanın çocuklarının normal kilolu ebeveynlerin çocuklarına kıyasla şişmanlık riski daha fazladır (8). Bu ailelerin çocukları önceden değerlendirilip beklenen kilo alımı olmadan tedbir alınabilir. Besleme tarzının belirlenmesinde izlem faydalı görünmektedir ancak pratikte uygulaması zordur. Literatürde, çocuklardaki şişmanlık riski ile ebeveynlerin besleme tarzı arasındaki ilişkiyi araştıran az sayıda çalışma bulunmaktadır. Bir yaklaşıma göre, ailelerdeki beslenme tarzının çocuklardaki kilo alımı ile ilişkili olduğu varsayımı üzerinde durulmuş ancak tutarlı sonuçlar elde edilememiştir. Ebeveynlerin istemleri ve yemek yeme için teşvikleri bazı çalışmalarda çocukların kilosu ile ilgili olarak olumlu yönde $(9,10)$ etkili olur iken, diğer bir çok çalışmada da olumsuz yönde $(11,12)$ etkili olduğu bulunmuştur. Ayrıca, incelenen sınırlı sayıdaki çalışmalarda şişman olan ve şişman olmayan çocukların ebeveynleri arasında davranış kontrollerinde anlamlı bir fark bulunmamıştır $(7,13)$.

Şişmanlığın çocukluk döneminde başladığı ve bu nedenle de ebeveyn şişmanlığının ileri yaşlardaki şişmanlık için risk etmeni olduğu yaygın bir düşüncedir $(14,15)$. Şişman olan ve olmayan ebeveynlerdeki beslenme tarzının klyaslanması ve ebeveyn davranışları, şişmanlık riskinin nesiller arası aktarımının bir belirtisi olabilir. Ayrıca genetik etmenlerin de kilo alımı gibi ailevi benzerliklere katkıda bulunduğuna dair güçlü kanıtlar vardır $(16,17)$. Bununla birlikte kilodaki değişimin yaklaşık olarak dörtte biri çevresel etkenler tarafindan meydana gelmekte ve ebeveynin besleme tarzı, çevre etkisinin bir parçası olabilmektedir.
Bu çalışma ebeveynlerin farklı bir besleme tarzı kullanıp kullanmadığını belirlemek amacıyla tasarlanmıştır. Besleme tarzı; duygusal (emosyonel) besleme, yardımcı (enstrümental) besleme, yemeye teşvik/cesaret verme (yiyeceği ödül olarak kullanma), ve aşırı yemeyi kontrol etme şeklinde değerlendirilmiştir.

Çalışmamızda ebeveyn besleme alışkanlığını ölçünlüleştiren (standardize eden) Parental Feeding Style Questionnaire (PFSQ) anketinin Türkçeye uyarlanması ve sonraki çalışmalara kolaylık getirmesi amaçlanmıştır.

\section{Gereç ve Yöntem}

Mayıs-Haziran 2008 tarihleri arasında Gaziosmanpaşa Üniversitesi Tıp Fakültesi Çocuk Bilim Dalı polikliniğine başvuran çocukların aileleri ve Tokat ilindeki anaokulu ve anasınıflarına devam eden öğrencilerin anne babaları örnek olarak alınmıştır. Polikliniğe başvuran kronik bir hastalığı olmayan 2-9 yaş arası çocuk hastaların muayene işlemleri tamamlandıktan sonra ebeveynlerine çalışma hakkında bilgi verilip anketi doldurmaları teklif edilmiştir. Kabul edenlerden anketi doldurmak için yeterli zihinsel kapasiteye sahip olanlar dahil edilmiştir. Onam formu okunmuş kabul etmeleri durumunda imzalatılıp demografik bilgilerin olduğu kısım doldurulmuştur.

Okullardaki çalışma için Üniversitemiz Rektörlüğü ve Tokat İ Milli Eğitim Müdürlüğü arasında resmi yazışmalar ile gerekli izinler alınmıştır. Biyoistatistik AD tarafından örneklem sayısı ve hangi okullardan denek alınacağı belirlendikten sonra bu okulların ana sınıfı ve anaokulu öğretmenleri ile görüşülüp zarf içinde anket soruları öğrenci aracılığı ile ebeveyne ulaştırılmıştır. Beş gün sonra cevap verilip geri gönderilen anket formları toplanmıştır. Öğretmenler tarafından ölçülen boy ve kilo bilgileri alınmıştır. 550 adet anket öğrenciler ile gönderilmiş ve bunlardan 405'sı geri dönmüştür, hastanede ise 98 anket uygulanmıştır.

Ebeveyn Besleme Tarzı Anketinin Türk çocuklarında geçerlik ve güvenirlik çalışmasını yapabilmek için öncelikle anketi geliştiren J Wardle'dan yazılı izin alınmıştır. Anket, önce iyi derecede İngilizce bilen, Amerika ya da İngiltere'de en az beş yıl yaşamış üç öğretim üyesi tarafından İngilizce'den Türkçe'ye çevrilmiştir. Bu üç çeviri gözden geçirilip en uygun ifadelerden Türkçe metin elde edilmiştir. Yine iyi derecede İngilizce bilen önceki üç öğretim üyesinden farklı bir öğretim üyesine de Türkçe'den İngilizce'ye çevirisi yaptırılmıştır. Bu İngilizce metin özgün anket metni ile karşılaştııılmış ve önemli anlam değişikliği tespit edilmemesi üzerine 30 ebeveyne uygulan- 
mıştır. Anlaşıımayan, ifade eksikliği olduğu bildirilen sorular tekrar gözden geçirilip gerekli düzeltmeler yapıldıktan sonra anket çoğaltılarak araştırmaya başlanmıştır.

Yirmi yedi maddeden oluşan ölçek faktör analizi ile yeniden değerlendirilmiş, ana bileşenler yöntemi ile faktör yapıları belirlenmiştir. Faktör analizine göre elde edilen alt ölçekler geçerlilik ve güvenirlik yönünden soru analizi ile tekrar değerlendirmeye alınmış ve Cronbach Alfa katsayıları hesaplanmıştır. Tüm alt ölçeklerin Tukey toplanabilirlik testine göre toplanabilirlik özelliği göstermesinden dolayı alt ölçekleri oluşturan soruların puanları toplanmış ve alt ölçek puanları elde edilmiştir. Bu alt ölçek puanlarının tanımlayıcı istatistikleri hesaplanmış, yaş gruplarına göre ve cinsiyetlere göre tek yönlü varyans analizi (ikili karşılaştırmalarda Sheffe testi kullanıldı) ve bağımsız iki örneklem t testleri ile karşılaştırmalar yapılmıştır. Ölçek puanları aritmetik ortalama ve standart sapma ile gösterilmiş, p değerleri 0,05 'in altında hesaplandığında istatistiksel olarak önemli kabul edilmiştir. Hesaplamalar istatistik paket programı ile yapılmıştır. (PASW ver.18, ID:33478001 SPSS inc. Chicago, IL)

\section{Araştırmanın kısıtlılıkları}

- Güvenirlik değerlendirmesinde test tekrar test yöntemi kullanılmamıştır.

- Türkçe'de benzer bir test olmadığından eş değerli ölçek güvenirliği ve eş zamanlı geçerlik değerlendirmesi yapılamamıştır.

\section{Bulgular}

\section{Ebeveyn besleme tarzı anketi (EBTA)}

İki yüz kırk üç erkek ve 225 kız çocuğun toplam 468 ebeveynine anket uygulanmıştır. Çocukların \%51,9'unu erkekler, \%48,1'ini kızlar oluşturmuştur. Yaş ortalaması $5,84 \pm 1,28$ yll, boy ortalaması $114,95 \pm 9,92 \mathrm{~cm}$, kilo ortalaması ise $20,96 \pm 4,68 \mathrm{~kg}$ olarak bulunmuştur.

Annelerin yaş ortalaması $31,05 \pm 4,57 \mathrm{yll}$, boy ortalaması $162,69 \pm 6,16 \mathrm{~cm}$, kilo ortalaması ise $65,72 \pm 10,97 \mathrm{~kg}$ 'dır. Babaların yaş ortalaması $35,08 \pm 5,04 \mathrm{yıl}$, boy ortalaması $173,38 \pm 9,74 \mathrm{~cm}$, kilo ortalaması $78,75 \pm 11,84 \mathrm{~kg}$ 'dır.

Çocukların \%25,8'i $(n=120)$ ilk altı ay, \%54,9'u (n=256) 12 aydan fazla anne sütü almıştır. $313(\% 66,9)$ olguya vitamin takviyesi, $289(\% 61,8)$ olguya demir takviyesi verilmiştir.

Okullarda öğrenciler aracıllğıyla velilere gönderilen anketlerden geri dönenlerden 35 çocukta kronik bir hastalık olduğu saptanmış ve bunlar araştırmadan çıkarılarak okuldan gelen 370 anket ve hastanede uygulanan 98 anket ile istatistiksel değerlendirmeler yapılmıştır.

\section{Güvenirlik çalışması ile ilgili bulgular}

Ebeveyn besleme tarzı anketi, ebeveynlerin yanıtladığı, 27 maddelik, 5 puan üzerinden değerlendirilen (1=asla-5=her zaman) Likert tipi bir ankettir. Anketteki maddeler şişmanlık ile ilgili önceki literatür bilgilerinden ve ebeveyn ile görüşmelerden elde edilen veriler ile oluşturulmuştur. Ölçeğin geliştirildiği özgün çalışmada, anketin geliştirilmesi sırasında dört alt ölçekli faktör yapısı oluşturulmuş, dört alt ölçeğin Cronbach alfa katsayıları 0,67 ile 0,83 arasında değişmiştir. Bu sonuçlara dayanılarak EBTA'nın ebeveyn besleme alışkanlığını değerlendirmesinde geçerli ve güvenilir olduğu belirlenmiş ve Türkçe'ye çevrilerek uygulanmıştır.

Türkçe'ye çevrilen anketin yapısını doğrulamak ve özgün anket ile benzer olduğunu göstermek için 27 maddenin faktör analizi yapıldı. Dört alt ölçeği olan özgün anket, çalışmamızda beş alt ölçeğe ayrıldı. Cronbach Alfa katsayısının ise 0,54 ile 0,83 arasında değiştiği saptandı. Tablo 1 ve 2'de faktör analizi sonuçları gösterilmiştir.

Tablo 1. Faktör yapıları ve faktör yükleri (Varimax rotasyonlu)

\begin{tabular}{|l|c|c|c|}
\hline Faktör yapıları & $\begin{array}{l}\text { Faktör } \\
\text { yükleri }\end{array}$ & $\begin{array}{c}\text { Faktör } \\
\text { yapılları }\end{array}$ & $\begin{array}{c}\text { Faktör } \\
\text { yükleri }\end{array}$ \\
\hline DB & 0,664 & YB & \\
2. soru & 7. soru & 0,578 \\
13. soru & 0,744 & 9. soru & 0,405 \\
15. soru & 0,747 & 18. soru & 0,579 \\
21. soru & 0,791 & 22. soru & 0,506 \\
25. soru & 0,764 & & \\
\hline CN & 0,280 & SK & \\
3. soru & 0,476 & 17. soru & 0,486 \\
4. soru & 0,564 & 20. soru & 0,596 \\
6. soru & 0,397 & 26. soru & 0,730 \\
8. soru & 0,661 & TK & \\
10. soru & 0,719 & 1. soru & 0,670 \\
12. soru & 0,676 & 11. soru & 0,616 \\
19. soru & 0,537 & 14. soru & 0,573 \\
27. soru & & 16. soru & 0,457 \\
& & 23. soru & 0,276 \\
\hline
\end{tabular}

Tablo 2. Alt ölçeklere göre iç güvenirlik (Cronbach Alfa) katsayıları

\begin{tabular}{|l|c|c|}
\hline Alt ölçekler & Cronbach alfa (-) & $\begin{array}{c}\text { Soru-bütün } \\
\text { korelasyonları (Range) }\end{array}$ \\
\hline DB & 0,83 & $0,562-0,667$ \\
CB & 0,74 & $0,326-0,513$ \\
\hline YB & 0,64 & $0,331-0,508$ \\
\hline SK & 0,69 & $0,449-0,490$ \\
\hline TK & 0,54 & $0,248-0,355$ \\
\hline
\end{tabular}


Sonuç olarak yapı geçerliği ve iç tutarlığı yönünden ayrıca alt grup ilişkileri açısından özgün anket ile çok yakın sonuçlar elde edilmiştir.

Faktör analizi

Yapılan faktör analizi sonucunda ölçeğin, duygusal (emosyonel) besleme (DB), yardımcı (enstrümental) besleme (YB), yemeye teşvik/cesaretlendirici besleme (CB) (yiyeceği ödül olarak kullanma) ile sıkı kontrollü (SK) ve toleranslı kontrollü (TK) besleme şeklinde beş alt ölçeğe ayrılabileceği bulundu (Tablo 1). Faktörlerin büyük çoğunluğu Wardle ve ark.'larının (6) özgün çalışması ile benzer bulunmuştur, ancak faktör analizinde özgün ankette bulunan kontrollü besleme alt ölçeğinin çalışmamızda iki farklı alt ölçeğe (SK ve TK) ayrıması gerektiği ortaya çıkmıştır. Güvenirlik katsayıları (Cronbach Alfa) Tablo 2'de, alt ölçek toplam puanları ise Tablo 3'de verilmiştir.

\section{Güvenirlik çalışması ile ilgili bulgular}

Sonuç olarak soru bütün korelasyonu 0,248 ile 0,667 arasındadır, "iyi" olarak değerlendirilmiştir.

Cesaretlendirici besleme ile TK ve DB ile SK dışında tüm alt ölçekler birbirleriyle ilişkili bulunmuştur. Bunlardan kontrollü beslemeyi belirten SK ve TK alt ölçekleri arasında ters yönde zayıf bir ilişki saptanmıştır (Tablo 4).

Alt ölçek puanları yönünden yaş grupları arasında yapılan karşılaştırmalara göre yaş grupları arasında istatistiksel olarak fark bulunmadı (Tablo 5).

Alt ölçekler ile yaș arasındaki ilişkiler değerlendirildiğinde yaş ile DB arasında aynı yönde, zayıf ve istatistiksel olarak önemli ilişki, yaş ile CB, SK ve TK arasında ise ters yönde, zayıf ve istatistiksel olarak önemli ilişki bulundu (Tablo 6).

Alt ölçek puanları yönünden cinsiyetler arasında yapılan karşılaştırmalara göre erkek ve kızlar arasında istatistiksel olarak fark bulunmadı.

Tablo 3. Ebeveyn besleme tarzı anketi alt ölçekleri arasındaki Pearson's bağıntı katsayıları (n 468)

\begin{tabular}{|c|c|c|c|c|c|}
\hline & DB & CB & YB & SK & TK \\
\hline DB & 1 & - & - & - & - \\
\hline CB & $0,233^{\star}$ & 1 & - & - & - \\
\hline YB & $0,468^{\star}$ & $0,148^{\star}$ & 1 & - & - \\
\hline SK & 0,085 & $0,359^{\star}$ & $0,204^{\star}$ & 1 & - \\
\hline TK & $0,283^{\star}$ & 0,081 & $0,119^{\star}$ & $-0,212^{\star}$ & 1 \\
\hline
\end{tabular}

*: $p<0,05$

Tablo 4. Alt ölçek toplam puanlarının dağılımı

\begin{tabular}{|c|c|c|}
\hline & Alt Ölçekler & Ort \pm SS \\
\hline DB & & $13,24 \pm 4,22$ \\
\hline CB & & $31,25 \pm 5,08$ \\
\hline YB & & $9,67 \pm 3,21$ \\
\hline SK & & $13,73 \pm 3,52$ \\
\hline TK & & $12,64 \pm 3,52$ \\
\hline
\end{tabular}

Tablo 5. Yaş gruplarına göre alt ölçek toplam puanlarının dağııımı

\begin{tabular}{|c|c|c|c|c|c|}
\hline & & $\mathbf{n}$ & Ort $\pm S S$ & $\mathbf{F}$ & p \\
\hline \multirow{4}{*}{ DB } & 3- Yaş & 38 & $12,61 \pm 4,26$ & 0,926 & 0,819 \\
\hline & 4 Yaş & 23 & $13,43 \pm 3,50$ & - & - \\
\hline & 5 Yaş & 42 & $13,21 \pm 4,33$ & - & - \\
\hline & 6 Yaş & 247 & $12,86 \pm 4,05$ & - & - \\
\hline \multirow{6}{*}{ CB } & $7+$ Yaş & 118 & $14,21 \pm 4,53$ & - & - \\
\hline & 3- Yaş & 38 & $32,32 \pm 5,66$ & 2,669 & 0,819 \\
\hline & 4 Yaş & 23 & $31,87 \pm 3,90$ & - & - \\
\hline & 5 Yaş & 42 & $31,17 \pm 4,54$ & - & - \\
\hline & 6 Yaş & 247 & $31,56 \pm 4,70$ & - & - \\
\hline & $7+$ Yaş & 118 & $30,14 \pm 5,86$ & - & - \\
\hline \multirow{5}{*}{ YB } & 3- Yaş & 38 & $9,47 \pm 3,62$ & 0,703 & 0,872 \\
\hline & 4 Yaş & 23 & $10,00 \pm 3,18$ & - & - \\
\hline & 5 Yaş & 42 & $9,76 \pm 3,62$ & - & - \\
\hline & 6 Yaş & 247 & $9,67 \pm 3,24$ & - & - \\
\hline & $7+$ Yaş & 118 & $9,62 \pm 2,90$ & - & - \\
\hline \multirow{5}{*}{ SK } & 3- Yaş & 38 & $14,24 \pm 3,60$ & 7,752 & 0,051 \\
\hline & 4 Yaş & 23 & $15,48 \pm 3,23$ & - & - \\
\hline & 5 Yaş & 42 & $14,00 \pm 3,22$ & - & - \\
\hline & 6 Yaş & 247 & $13,70 \pm 3,51$ & - & - \\
\hline & $7+$ Yaş & 118 & $13,20 \pm 3,56$ & - & - \\
\hline \multirow{5}{*}{ TK } & 3- Yaş & 38 & $14,21 \pm 4,15$ & 5,297 & 0,151 \\
\hline & 4 Yaş & 23 & $12,43 \pm 3,41$ & - & - \\
\hline & 5 Yaş & 42 & $12,29 \pm 3,68$ & - & - \\
\hline & 6 Yaş & 247 & $12,77 \pm 3,43$ & - & - \\
\hline & $7+$ Yaş & 118 & $12,03 \pm 3,34$ & - & - \\
\hline
\end{tabular}

Tablo 6. Yaş ile alt ölçekler arasındaki bağıntı katsayıları (r)

\begin{tabular}{|l|c|c|c|c|c|} 
& DB & CB & YB & SK & TK \\
\hline Yaş & $0,100^{\star}$ & $-0,096^{\star}$ & 0,012 & $-0,116^{\star}$ & $-0,100^{\star}$ \\
\hline
\end{tabular}

*: $p<0,05$

Tablo 7. Cinsiyetlere göre alt ölçek toplam puanlarının dağııımı

\begin{tabular}{|c|c|c|c|c|c|}
\hline & & $\mathbf{n}$ & Ort $\pm S S$ & $\mathbf{Z}$ & p \\
\hline \multirow{2}{*}{ DB } & Erkek & 243 & $13,37 \pm 4,15$ & \multirow{2}{*}{0,892} & \multirow{2}{*}{0,373} \\
\hline & $\mathrm{KIz}$ & 225 & $13,10 \pm 4,29$ & & \\
\hline \multirow{2}{*}{ CB } & Erkek & 243 & $31,58 \pm 4,96$ & \multirow{2}{*}{1,524} & \multirow{2}{*}{0,128} \\
\hline & $\mathrm{KIz}$ & 225 & $30,88 \pm 5,18$ & & \\
\hline \multirow{2}{*}{ YB } & Erkek & 243 & $9,78 \pm 3,07$ & \multirow{2}{*}{0,807} & \multirow{2}{*}{0,420} \\
\hline & $\mathrm{KIz}$ & 225 & $9,54 \pm 3,36$ & & \\
\hline \multirow{2}{*}{ SK } & Erkek & 243 & $13,75 \pm 3,35$ & \multirow{2}{*}{0,117} & \multirow{2}{*}{0,907} \\
\hline & $\mathrm{KIz}$ & 225 & $13,71 \pm 3,69$ & & \\
\hline \multirow{2}{*}{ TK } & Erkek & 243 & $12,93 \pm 3,72$ & \multirow{2}{*}{1,730} & \multirow{2}{*}{0,084} \\
\hline & $\mathrm{KIz}$ & 225 & $12,34 \pm 3,28$ & & \\
\hline
\end{tabular}




\section{Tartışma}

Şişman ve normal kilolu çocuklarda, anne-babanın besleme tarzının karşılaştırılması, çalışmalar için iyi bir başlangıç noktası oluşturabilir. Bu alanda yapılan çok sayıda çalışmada, ailedeki bir çocuğa ait veriler kullanılmış ve bundan dolayı da her bir aile, şişman bir çocuğun ailesi ya da normal kilolu bir çocuğun ailesi olarak tanımlanmıştır. Kardeşler arası beslenme tarzını inceleyen araştırmalar çok azdır. Bunlardan sadece dört aileyi içeren bir çalışmada (18) anne ve babanın şişman erkek çocuklarına daha fazla yemek verdiği bulunur iken, 18 aile ile yapılan başka bir çalışmada (19) ise, şişman olan ve şişman olmayan kardeşler arasında beslenme alışkanlıklarında anlamlı bir fark bulunmamıştır. Diğer bir yaklaşım ise şişmanlık yönünden düşük ve yüksek riskli çocukların belirlenmesi ve bu iki grup arasındaki ebeveyn besleme tarzının karşılaştııımasıdır. Sallis ve ark.'ları (20) tarafından karşılıklı görüşme kullanılarak yapılan bir çalışmada $(n=247)$, yemeyi kontrol etme ve yiyeceği ödül olarak kullanma ile annenin şişmanlığı arasında bir ilişki bulunamamıştır. Daha geniş yapılan başka bir anket çalışmada ise $(n=634)$ aşırı kilolu annelerin, normal kilolu annelere göre daha az kontrollü besleme tarzı ile aşırı besleme alışkanlığı bildirilmiştir (21). Bizim de çalışmamıza kaynak olan Wardell ve ark.'larının (6) çalışmasında (Parental Feeding Style Questionnaire) 214 aile incelenmiş ve şişman ve normal kilolu ebeveynlerin duygusal besleme, yardımcı besleme ve yemeye teşvik ederek besleme (yiyeceği ödül olarak kullanma) yöntemleri eşdeğer bulunur iken, şişman annelerin çocuklarının beslenmesinde daha düşük kontrol sağladıkları saptanmıştır (6).

Çalışmamızda "Parental Feeding Style Questionnaire" Türkçe uyarlamasının faktör yapısı, geçerlik ve güvenirliğinin özgün anket ile uyumlu olduğu gösterildi. Ancak Türkçe anketin içgeçerlik ve güvenirliğinin uygun olması için özgün ankette bulunan kontrollü besleme alt ölçeğinin çalışmamızda iki farklı alt ölçeğe (SK ve TK) ayrılması gerekti. Bununla birlikte SK ve TK alt ölçekleri arasında ters yönde zayıf bir ilişki saptadık. Bunun nedeni ise toplumun iç dinamiklerinin özelliği olarak değerlendirildi. Öyle ki, ebeveynler yasaklayıcı davranış özelliklerini benimsemiş iken aynı zamanda çocuğa izin verici yaklaşımlardan kaçınmaktadır. Başka bir deyişle ebeveynler, yemek yeme ile ilgili katı kuralları benimsedikleri takdirde çocuklarına seçme hakkı tanımamaktadırlar. Ebeveynlerin uyguladığı kontrolün şişmanlık riskini azaltmakta başarıı olup olamayacağı veya bu şekildeki kontrolün sadece özdenetime sahip olmayan çocuklar yetiştirip yetiştirmeyeceğine iliş̧in devam eden tartışmaların ışığında bu konunun araştırmaya değer olduğu görünmektedir.

Yaş ile besleme tarzı karşılaştıııldığında, DB arasında aynı yönde, zayıf ve istatistiksel olarak önemli ilişki, CB, SK ve TK arasında ise ters yönde, zayıf ve istatistiksel olarak önemli ilişki bulundu. Bu durum annenin çocuklarına kendine davrandığı şekilde davranmaya eğilimi olduğunu ya da daha kesin olmayan bir biçimde, duygusal beslenme alışkanlığı olan annelerin, çocuklarını duygusal olarak stres altında olduklarında beslemeye daha yatkın oldukları ve annesel besleme uygulamasının da buna yanit veren biçimde olduğu şeklinde yorumlanabilir.

Bu anketin kısıtlayıcı özelliği ise, ebeveynlere ait besleme tarzının yine ebeveynler tarafından bildirilmesiydi, her ne kadar bu araştırmada kullanılan aracın içsel olarak tutarlı ve zaman içerisinde güvenilir olduğu kanıtlanmış olsa da bu durum bize ebeveynlerin kendi besleme alışkanlıklarını düzgün ve doğru bir biçimde aktarıp aktarmadıklarına ilişkin bir bilgi vermemektedir. Aynı kısıtlama bu alanda yapılan neredeyse tüm araştırmalar için geçerlidir. Aile yemeklerini gözlemlemeye dayalı araştırmalar $(12,13)$ mevcuttur ancak bu araştırmalar da reaktivite hakkında endişeleri ortaya çıkartmaktadır. Gelecekteki çalışmaların bu alandaki araşıırmaları ileriye taşınması için, besleme davranışı hakkındaki ebeveyn raporlarının geçerliliğini ele alması gereklidir. En önemlisi; bu veriler, ebeveynlerin besleme uygulamalarını göstermekte, ancak besleme uygulamaları ve şişmanlığın gelişimi arasında doğrudan bir ilişki olduğunu göstermemektedir. Ebeveyn besleme tarzı ve çocukların kilosu arasındaki ilişkinin kanıtlarının, uzun süreli gözleme dayalı çalışmalar yoluyla ortaya koyulması gerekmektedir. Bir çocuk için besleme ortamının bir parçası olarak ve genetik şişmanlık riskini azaltabilecek herhangi bir ebeveyn besleme tarzı olup olmadığını gösterecek izlemsel çalışmalarda bir durgunluk yaşanmaktadır. Son yıllarda gözlemlenen şişmanlıktaki çarpıcı artışlar (22) ve özellikle çocukluk dönemindeki şişmanlık artışı göz önüne alındığında, çocukluk döneminde şişmanlık gelişimi üzerine yapılacak araştırmalara yönelik yatıııma öncelik verilmesi gerekmektedir.

\section{Teşekkür}

Anketin çevirilerini yapan üniversitemiz değerli öğretim üyelerine, Tokat II Milli Eğitim Müdürlügü Yetkililerine, Tokat il Merkezinde bulunan tüm ilköğretim müdürlerine, anketlerin velilere iletilmesinde içten yardımlarını esirgemeyen anasınıfı ve anaokulu öğretmenlerine, anketi bıkmadan tamamlayıp bize geri ulaştıran tüm anne babalara teşekkür ederiz. 


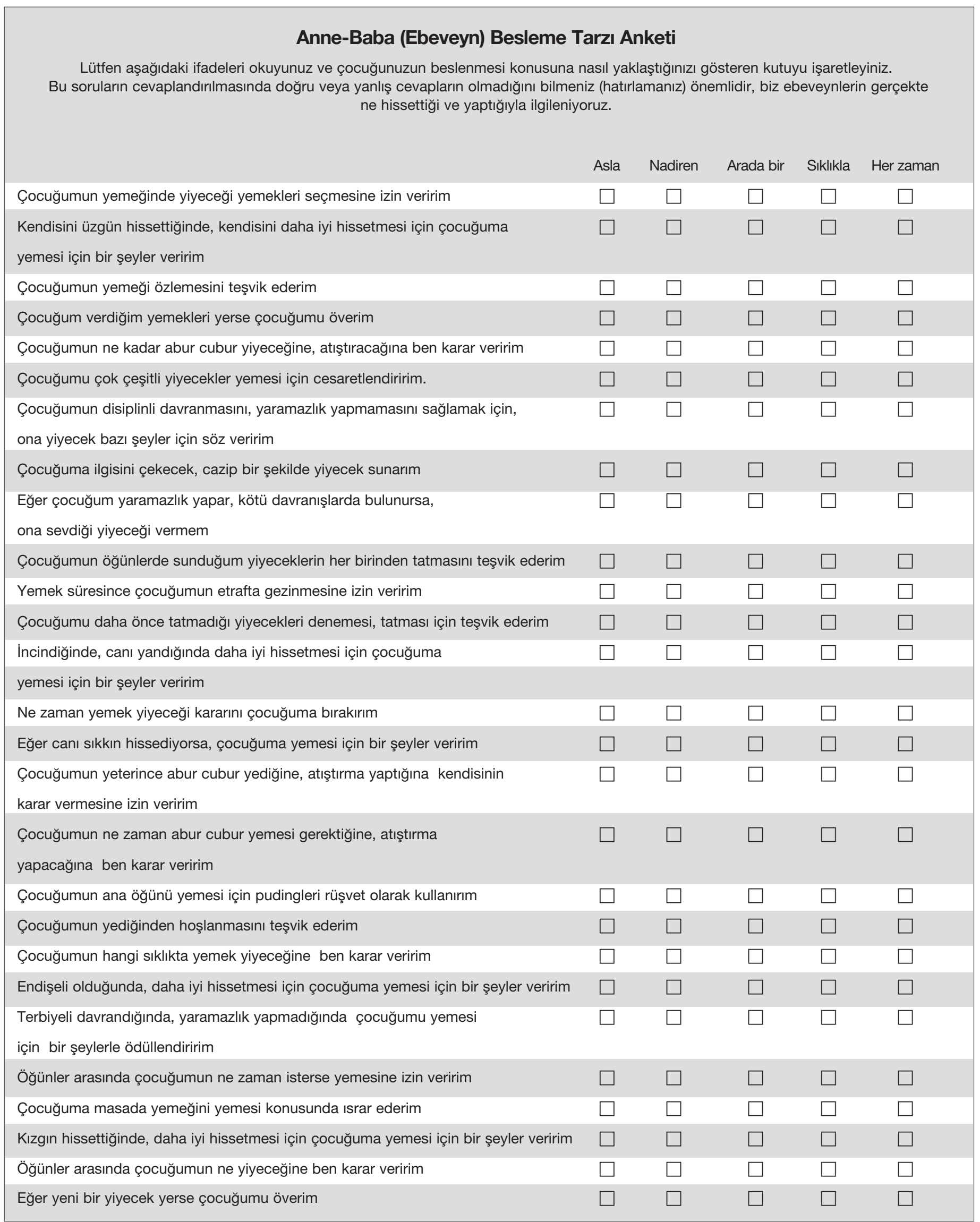




\section{Parental Feeding Style Questionnaire}

Please read the following statements and tick the appropriate boxes to show how you deal with feeding your child. It is important to remember that there are no right or wrong answers to these questions, we are interested in what parents really feel and do.

I allow my child to choose which foods to have for meals

$\mathrm{C}^{*}$

I give my child something to eat to make him/her feel better when $s /$ he is feeling upset

I encourage my child to look forward to the meal

I praise my child if $\mathrm{s} / \mathrm{he}$ eats what I give him/her

I decide how many snacks my child should have

I encourage my child to eat a wide variety of foods

In order to get my child to behave him/herself I promise him/her something to eat

I present food in an attractive way to my child

If my child misbehaves I withhold his/her favourite food

I encourage my child to taste each of the foods I serve at mealtimes

I allow my child to wander around during a meal

I encourage my child to try foods that s/he hasn't tasted before

I give my child something to eat to make him/her feel better when $\mathrm{s} /$ he has been hurt

I let my child decide when s/he would like to have her meal

I give my child something to eat if $s / h e$ is feeling bored

I allow my child to decide when s/he has had enough snacks to eat

I decide when it is time for my child to have a snack

I use puddings as a bribe to get my child to eat his/her main course

I encourage my child to enjoy his/her food

I decide the times when my child eats his/her meals

I give my child something to eat to make him/her feel better when $\mathrm{s} / \mathrm{he}$ is worried

I reward my child with something to eat when s/he is well behaved

I let my child eat between meals whenever s/he wants

I insist my child eats meals at the table

I give my child something to eat to make him/her feel better when $\mathrm{s} /$ he is feeling angry

I decide what my child eats between meals

I praise my child if $\mathrm{s} /$ he eats a new food

Scoring (1- 5)

Instrumental feeding = Mean I

Control $=$ Mean C

Emotional feeding $=$ Mean EM

Encouragement $=$ Mean EN

$*$ reversed item
EM

EN

EN

C

EN

I

EN

I

EN

$\mathrm{C}^{\star}$

EN

EM

$\mathrm{C}^{\star}$

EM

$\mathrm{C}^{*}$

C

I

EN

C

EM

I

$\mathrm{C}^{\star}$

C

EM

C

EN 


\section{Kaynaklar}

1. Marchi M, Cohen P. Early childhood eating behaviors and adolescent eating disorders. J Am Acad Child Adolesc Psychiatry 1990; 29: 112-7. (Abstract)

2. Ritchie LD, Welk G, Styne D, Gerstein DE, Crawford PB. Family environment and pediatric overweight: what is a parent to do? J Am Diet Assoc 2005; 105: 70-9. (Abstract) / (Full Text) / (PDF)

3. Bruch H. Developmental considerations of anorexia nervosa and obesity. Can J Psychiat 1981; 26: 212-7. (Abstract)

4. Brink PJ, Ferguson K, Sharma A. Childhood memories about food: the successful dieters project. J Child Adolesc Psychiat Nurs 1999; 12: 17-25. (Abstract) / (PDF)

5. Baughcum AE, Burklow/ KA, Dieks CM, Powers SW, Whitaker RC. Maternal feeding practices and childhood obesity: a focus group study of low-income mothers. Arch Pediat Adolesc Med 1998; 152: 1010-4. (Abstract) / (Full Text) / (PDF)

6. Wardle J, Sanderscn S, Guthrie CA., Rapssport L, Plomin R. Parental feeding style and the inter-generational transmission of obesity risk. Obes Res 2002; 10: 453-62. (Abstract) / (Full Text) / (PDF)

7. Costenzo PR, Woody EZ. Domain-specific parenting styles and their impact on the child's development of a particular deviance: the example of obesity proneness. J Soc Clin Psychol 1985; 3: 425-45.

8. Whitaker RC, Deeks CM, Baughcum AE. Specker BL. The relationship of childhood adiposity to parent body mass index and eating behavior. Obes Res 2000;8:234-40. (Abstract) / (Full Text) / (PDF)

9. Klesiges RC, Coates TJ, Brown G, et al. Parental influences on children's eating behavior and relative weight. J Appl Behav Anal 1983; 16: 371-8. (Abstract) / (Full Text) / (PDF)

10. Klesges RC, Stein RJ, Eck LH. Is.bell TR, K.lesces LM. Parental influence on food selection in young children and its relationships to childhood obesity. Am J Clin Nutr 1991; 53: 859-64. (Abstract) / (PDF)

11. Patterscin RE, Typp э JT, Typpo MH, Krause GF. Factors related to obesity in preschool children. J Am Diet Assoc 1991; 86: 1376-81. (Abstract)
12. Drucker RR, Hammer LD, Agras WS, Bryson S. Can mothers influence their child's eating bıhaviour? J Develop Behav Pediatr 1999; 20: 88-92. (Abstract)

13. Koivisto UK, Fellenius J, Sjoden PO. Relations between parental mealtime practices anc children's tord intake. Appetite 1994; 22: 245-57. (Abstract) / (PDF)

14. Edwards C, Nicholls D, Croker H, Van Zyl S, Viner R, Wardle J. Family-based behavioural treatment of obesity: acceptability caiıú éffectiveiñessi ir tíie UK. Eur J Clin Nutr 2006; 60: 587-92. (Ábstract) / (Fuii Text) / (F̄̄Fi)

15. Lake JK, Power C, Cade TJ. Child to adult body mass index in the 1958 British birth cohort: associations with parontal chosity. Arch Dis Child 1997; 77: 376-81. (Âüsiauii) / (Full Texi) / (FDFi)

16. Faith MS, Berkowitz RI, Stallings VA, Kerns J, Storey M, Stunkard AJ. Parental feeding attitudes and styles and child body mass index: prospective analysis of a gene-environment interaction. Pediatrics 2004; 114: 429-36. (Abstract) / (Fun! Text) / (PDF)

17. Koeppen-Schamerus G, Wardle J, Plomin R. A genetic analysis of weight and overweight in four year old twin pairs. Int $J$ Obes Relat Metab Disord 2001; 25: 838-44. (Aostract) / (Full Text) / (FDF)

18. Waxman M, Stunkard AJ. Caloric intake and expenditure of obese boys. J Pediatr 1980; 96: 187-93. (Asstract) / (PDF)

19. S'aelıns BE, Ernst MM, Epstein LH. Maternal child feeding practices and obesity: a discordant sibling analysis. Int $\mathrm{J}$ Eat Relat Metab Disord 2000; 27: 459-63. (Abstract) / (PDF)

20. Sallis JF, Broyles SL, Frank-Spohrer ('̇, Berry CC, Davis $\bar{T} \overline{\mathrm{B}}$, Nader PR. Child's home environment in relation to the mother's adiposity. Int J Obes Relat Metab Disord 1995; 19: 190-7. (Abstract)

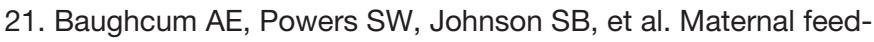
ing practices and beliefs and their relationships to overweight in early childhood. J Dev Behav Pediatr 2001; 22: 391-408. (Abstract)

22. W/ard!e J, Carnell S. Parental feeding practices and children's wicight. Acta Paediatr 2007; 96 :5-11. (Abstract) / (Full Text) / (PDF) 